\title{
甲状腺乳頭癌細胞診における DU-PAN-2 免疫染色の有用性
}

神奈川県立がんセンター 1), 藤田保健衛生大学医学部第一病理学教室 ${ }^{2)}$, JA 神奈川県厚生連伊勢原協同病院 検查科 ${ }^{3)}$, 東海大学医学部基盤診療学系病理診断学 ${ }^{4)}$, 神奈川予防医学協会 5)

大金 直樹 1) 鴨志田伸吾 2) 佐籐 嘉洋 3) 中村満美子 1)

田村 猛 1) 梶原 博 ${ }^{4)}$ 安田 政実 ${ }^{4)}$ 長村 義之 ${ }^{4)}$

亀田 陽一1）飯田 萬一 1,5)

目的：甲状腺細胞診標本を対象に，I 型糖鎖抗原である DU-PAN-2 およびCA19-9 の発現を免疫 細胞化学的に検索し, 乳頭癌の鑑別診断におけるDU-PAN-2の細胞学的マーカーとしての有用性に ついて，両者の比較に基づいて検討した。

方法：組織学的に診断が確定された，穿刺吸引および手術材料捺印により採取された計 58 例の 甲状腺疾患細胞標本（乳頭癌 30 例, 滤胞性病変 15 例, その他 13 例) を対象とし, DU-PAN-2 お よびCA19-9 の発現を免疫細胞化学的に検索した. 判定基準は陽性を示す腫瘍細胞が $10 \%$ 以下を ,+ 10 ～ $50 \%$ 以下を $2+, 50 \%$ 以上を $3+$ とした.

成績：DU-PAN-2 およびCA19-9 の感度は，それぞれ乳頭癌：80\%，70\%，滤胞性腫瘍：0\%，7\% その他の病変 0\%, 15\%であり, 両抗原の乳頭癌に対する特異度はDU-PAN-2：100\%, CA19-9： 89\%であった．陽性細胞の多寊と染色性から検討してみると，CA19-9 に比べDU-PAN-2 の陽性細 胞が多く観察される傾向があった. また, DU-PAN-2 が陰性の場合, CA19-9 陽性細胞は少数であっ たのに対して, CA19-9 が陰性の場合は, DU-PAN-2 の陽性細胞が多く認められる傾向があった.

結論：甲状腺乳頭癌において DU-PAN-2 の感度, 特異度はともにCA19-9 のそれらょりもやや上 回る程度であった。しかしながら，とりわけCA19-9 陰性ないし弱陽性例では, DU-PAN-2 の陽性 細胞が多数認められる傾向がみられ, 甲状腺の細胞学的鑑別診断において DU-PAN-2 は乳頭癌の有 用なマーカーとなりうることが示唆された.

Key words : Thyroid disease - Papillary carcinoma — Immunocytochemistry DU-PAN-2 - CA19-9

\footnotetext{
Significance of immunocytochemical study of DU-PAN-2 in thyroid papillary carcinoma

Naoki OGANE ${ }^{1}$, C.T., I.A.C., Shingo KAMOSHIDA ${ }^{2)}$, C.T., I.A.C., Yoshihiro SATOU ${ }^{3)}$, C.T., I.A.C., Mamiko NAKAMURA ${ }^{1)}$, C.T., Takeshi TAMURA ${ }^{1)}$, C.T., Hiroshi KAJIWARA ${ }^{4)}$, M.D., Masanori YASUDA ${ }^{4)}$, M.D., R.Yoshiyuki OSAMURA4), M.D., F.I.A.C., Youichi KAMEDA' ${ }^{1}$, M.D., Manichi IIDA ${ }^{1,5)}$, M.D.

${ }^{1)}$ Department of Pathology and Cytology, Kanagawa Cancer Center

${ }^{2)}$ Department of Pathology, Fujita Health University School of
}

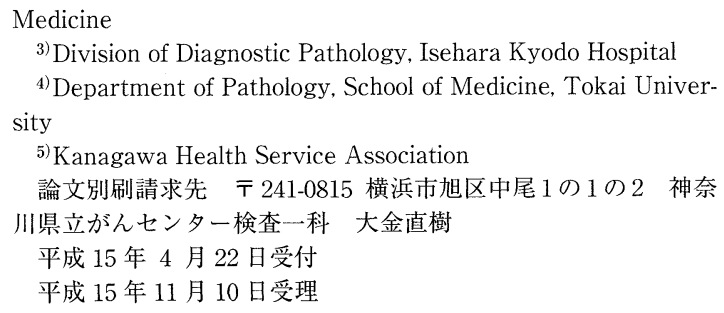




\section{I. はじめに}

Pancreatic cancer-associated antigen-2 (DU-PAN2) は膵臟癌培養細胞 ${ }^{1)}$ から, また, Carbohydrate antigen 19-9 (CA19-9) は大腸癌培養細胞 ${ }^{2)}$ から得ら れたモノクローナル抗体で認識されるI型糖鎖抗原で ある. DU-PAN-2 およびCA19-9 の生合成には特異的 糖転移酵素（ $a-2,3$ sialyltransferase， $a-1,4$ fucosyltransferase）が関与しており，DU-PAN-2 はCA19-9 の前駆物質に相当する ${ }^{3)}$ (Fig. 1). どちらの抗原も免 疫血清学的検査にて, 消化器癌の腫瘍マーカーとして 一般的に利用されている4 ${ }^{4-6)}$. また，これらのモノク ローナル抗体を用いた免疫組織化学的方法により, 消 化器系以外の正常および腫瘍組織でも興味深い発現の 意義が検討されている7 17).すなわち，これらI型 糖鎖抗原の発現が，発生および分化に伴って，さらに は腫瘍化の過程で, 変化することに着目して, その特 徵付けを明確に行うことは, 腫瘍の形態学的分類の一 助となることが期待される. 最近われわれは, 種々の 甲状腺疾患組織を対象にI 型糖鎖抗原の発現を免疫組 織化学的に検索し, 乳頭癌においては, DU-PAN-2の 発現が高頻度 (97\%) に認められ, 陽性反応は, 乳頭 状構造部および浸潤部の腫瘍細胞で顕著であることを 報告した ${ }^{11,12)}$ 。そこで今回は, 甲状腺細胞診断にお けるDU-PAN-2の有用性を確認すべく, アルコール固 定細胞標本への応用を試み検討を行ったので報告す る.

\section{II. 対象および方法}

組織学的に診断が確定された, 穿刺吸引および手術 材料捺印により採取された以下の 58 例の甲状腺疾患 細胞標本を対象とした. (乳頭癌 30 例, 滤胞癌 3 例, 滤胞腺腫 12 例, 好酸性細胞腺腫 1 例, 腺腫様甲状腺腫 8 例, 慢性甲状腺炎 1 例, バセドウ病 3 例.）パパニコ ロウ染色標本を分割して転写を行い, 脱色後, 䤉素抗 体間接法を用いて DU-PAN-2 および CA19-9 の免疫細 胞化学的検索を行った. 内因性ペルオキシダーゼを $0.3 \%$ 過酸化水素加メ夕ノール溶液で不活化した後, 一次抗体として DU-PAN-2（クローン DU-PAN-2，20 倍希釈, Kyowa Medex 社), CA19-9（クローン 1116NS-19-9，200 倍希釈，Fujirebio Diagnostics 社）を用 い, 室温にて一晚反応させた. 二次抗体は, シンプル ステイン MAX (ニチレイ社) で, 室温にて 30 分間反 応させ, DABで発色を行った。核染にはマイヤーの ヘマトキシリンを用いた。

判定基準は陽性細胞の割合が $10 \%$ 以下を+, 10 $50 \%$ 2+, $50 \%$ 以上を $3+$ とした. また, 各病変の 感度, 乳頭癌に対する特異度を以下の計算式にて算出 した. 感度 (陽性率) $(\%)=$ 陽性症例数 $/$ 全症例数 $\times$ 100 , 特異度 $(\%)=$ 乳頭癌以外の陰性症例数 / 乳頭癌 以外の全症例数 $\times 100$.

なお，検索した一部の症例に対して，組織標本でも DU-PAN-2 の免疫染色（酵素抗体間接法）を施行し, 細胞診標本の染色性と対比検討した。

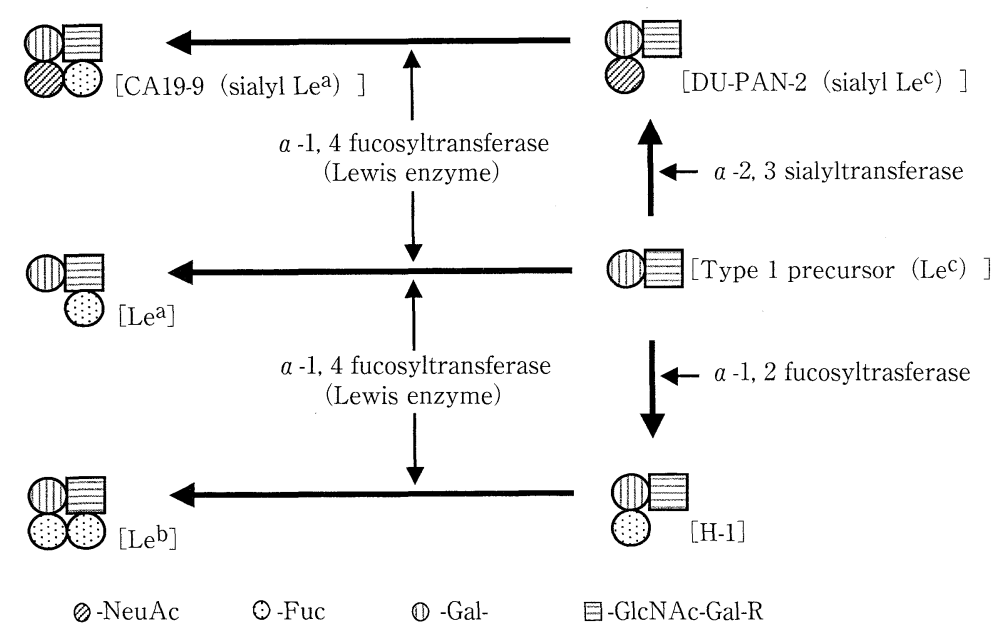

Fig. 1 Biosynthetic pathways of type 1 blood group antigens 


\section{III. 結 果}

甲状腺疾患 58 例における DU-PAN-2 およびCA19-9 の染色結果を Table 1 にまとめ, 特徴的な染色態度を Photo. 1, 2 に示した.

\section{1）抗原の発現局在}

両抗原の発現は, 乳頭癌においては, 腫瘍細胞の細 胞質にびまん性に, かつ細胞表面に膜様, 全周性に観 察された。また, CA19-9が他の疾患において, 陽性 を示す場合も, 同様の局在が認められた. なお，正常 滤胞上皮には, 明らかな陽性所見は観察されなかっ た.

\section{2）乳頭癌の感度}

DU-PAN-2 は乳頭癌の 80\%（24/30）に, CA19-9 は 70\%（21/30）に陽性であった。 2+以上の割合は, CA19-9が36\%であったのに対して, DU-PAN-2は50\% と,やや高い傾向を示した. 乳頭癌に特徵的な核所見 (核溝, 核内細胞質封入体) の有無と両抗原発現との 明らかな関わりは認められなかった。

\section{3）乳頭癌における特異度}

DU-PAN-2 およびCA19-9 の特異性はそれぞれ 100\%，89\%であった. DU-PAN-2 が陰性の症例では CA19-9 の陽性細胞が少数であったのに対して, CA199 が陰性の場合では DU-PAN-2 の陽性細胞が多数認め られる傾向を示した (Photo. 1，2).

\section{4）乳頭癌以外の疾患での感度}

DU-PAN-2 は乳頭癌以外の疾患において発現は認め られなかった. しかし, CA19-9では, 滤胞性腫瘍の 7\%（1/15）に，腺腫様甲状腺腫の 25\%（2/8）に陽性 所見が認められた.

\section{5）組織標本における染色性}

検討したいずれの症例においても染色性は，おおむ ね細胞診標本の染色性と同様の結果であった.

特に乳頭癌では, 全例が陽性を示し, apical membrane にDU-PAN-2 の局在がみられた（Photo. 3).

\section{IV. 考 察}

乳頭癌と濾胞癌はともに濾胞上皮に由来し, それら の多くは分化癌であるが, 転移形式が異なることにも 起因して予後に差がみられる。このような観点からも 両者の鑑別は重要であり, 病理組織標本を用いて乳頭 癌と濾胞癌を鑑別する目的で, 免疫組織化学的検討が いくつか報告されている11,12, 14,15,17 22, 24). われわれ が組織学的に検討した I 型糖鎖抗原発現の解析では, 乳頭癌のほぼ全例 $(97 \%: 37 / 38$ 例）に扔いて乳頭状 構造をとる部分, および周辺組織への浸潤性増殖を示 す腫瘍細胞に, DU-PAN-2の発現を認め, 陽性反応は apical membrane に局在していた。特に滤胞癌と鑑 別を要する滤胞型乳頭癌でも，同様にDU-PAN-2 の発 現を認めた 11,12). しかしながら，他の甲状腺腫瘍 $(0 \%: 0 / 60$ 例 $)$ および正常組織では発現がみられな かった ${ }^{11)}$. Vierbuchenらは, CA19-9について52例中 25 例（48\%）が陽性を示し，その他滤胞性腫瘍におい ても，51 例中 7 例 (14\%) が陽性と報告している. CA50に関しては，乳頭癌においては 52 例中 48 例 （92\%）が陽性で, 腫瘍性病変においては 52 例中 16 例 （31\%）が陽性であると述べている ${ }^{14)}$ 。また, 伊達ら は, CA19-9 は乳頭癌 33 例中 27 例 (82\%) に陽性で, 滤胞癌においても，8例中 3 例（38\%）が陽性を示し たと報告している ${ }^{15)}$. 今回われわれの細胞診標本に おける検討で, 感度および特異度とも, 相対的に

Table 1 Expression profiles of DU-PAN-2 and CA19-9 in thyroid disease

\begin{tabular}{|c|c|c|c|c|c|c|c|c|c|c|c|}
\hline \multirow[b]{2}{*}{ Disease } & \multirow[b]{2}{*}{ Cases } & \multicolumn{5}{|c|}{ DU-PAN-2 } & \multicolumn{5}{|c|}{ CA19-9 } \\
\hline & & - & + & ++ & +++ & Positive ratio & - & + & ++ & +++ & Positive ratio \\
\hline Papillary carcinoma & 30 & $6(20 \%)$ & $9(30 \%)$ & $11(37 \%)$ & $4(13 \%)$ & $24(80 \%)$ & $9(30 \%)$ & $10(33)$ & $10(33)$ & $1(3)$ & $21(70 \%)$ \\
\hline Follicular carcinoma & 3 & $3(100)$ & $0(0)$ & $0(0)$ & $0(0)$ & $0(0)$ & $3(100)$ & $0(0)$ & $0(0)$ & $0(0)$ & $0(0)$ \\
\hline Follicular adenoma & 12 & $12(100)$ & $0(0)$ & $0(0)$ & $0(0)$ & $0(0)$ & $11(92)$ & $0(0)$ & $1(8)$ & $0(0)$ & $1(8)$ \\
\hline Oxyphilic adenoma & 1 & $1(100)$ & $0(0)$ & $0(0)$ & $0(0)$ & $0(0)$ & $1(100)$ & $0(0)$ & $0(0)$ & $0(0)$ & $0(0)$ \\
\hline Adenomatous goiter & 8 & $8(100)$ & $0(0)$ & $0(0)$ & $0(0)$ & $0(0)$ & $6(75)$ & $2(25)$ & $0(0)$ & $0(0)$ & $2(25)$ \\
\hline Hashimoto's thyriditis & 1 & $1(100)$ & $0(0)$ & $0(0)$ & $0(0)$ & $0(0)$ & $1(100)$ & $0(0)$ & $0(0)$ & $0(0)$ & $0(0)$ \\
\hline Basedow's disease & 3 & $3(100)$ & $0(0)$ & $0(0)$ & $0(0)$ & $0(0)$ & $3(100)$ & $0(0)$ & $0(0)$ & $0(0)$ & $0(0)$ \\
\hline
\end{tabular}

DU-PAN-2 : Pancreatic cancer-associated antigen-2, CA19-9 : Carbohydrate antigen 19-9

+ : positive cells $10 \%<, 2+$ positive cells $10 \sim 50 \%, 3+$ positive cells $50 \%>$ 


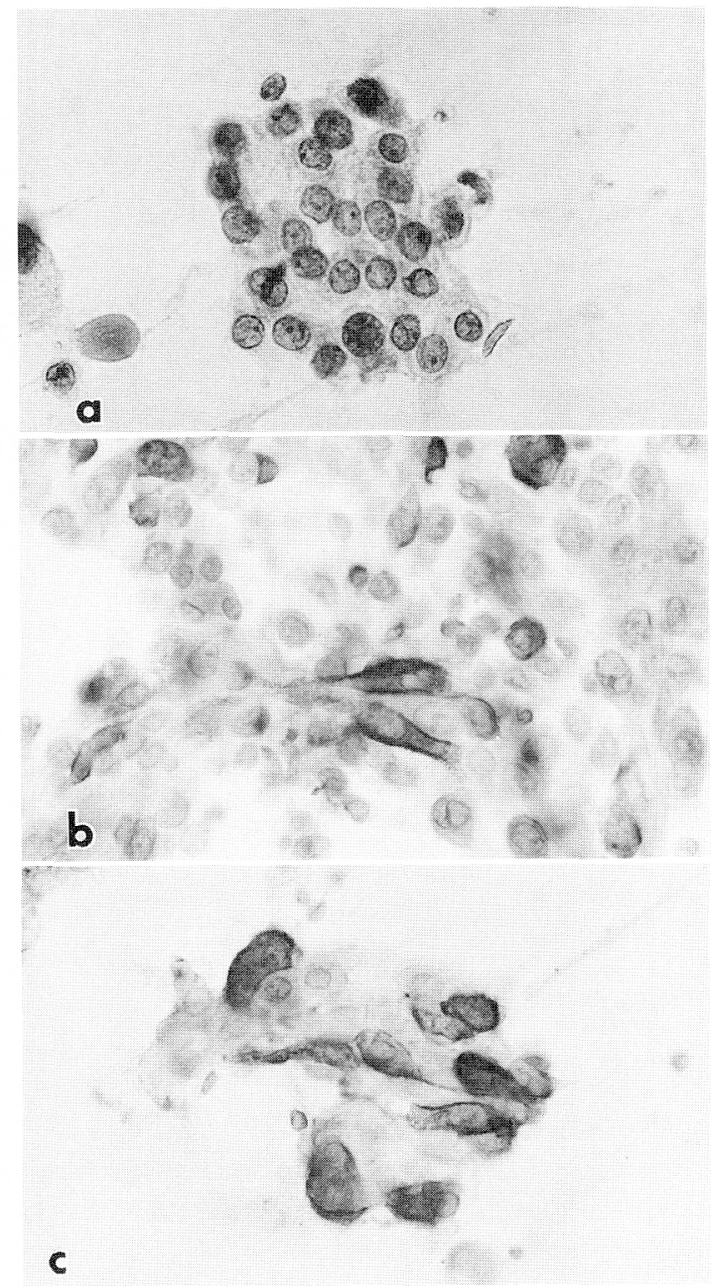

Photo. 1 (a) Pap. stain $\times 40$ : Clustered papillary carcinoma cells $(\times 40)$. (b) DU-PAN- $\times 40$ : A few papillary carcinoma cells show positive immunoreaction $(\times 40)$. (c) CA19-9 $\times 40$ : Corresponding to immunoreaction for DU-PAN-2, positive cells are relatively few $(\times 40)$.

CA19-9 より DU-PAN-2 が高く, 組織標本と同様アル コール固定標本においても，乳頭癌の鑑別に際し有用 性が高いことが示唆された。

通常, 甲状腺細胞診での乳頭癌の診断は, 特徵的な 細胞学的所見が明暸にみられる場合は比較的容易であ るが，それらが不明瞭な際はしばしば診断に苦慮す る。とりわけ，滤胞性腫瘍と滤胞型乳頭癌の鑑別は問 題となる.今回の検討では, 滤胞型乳頭癌の 1 例でも DU-PAN-2の発現を認め, 鑑別の手段としてDUPAN-2の有用性が高いことが示唆された。

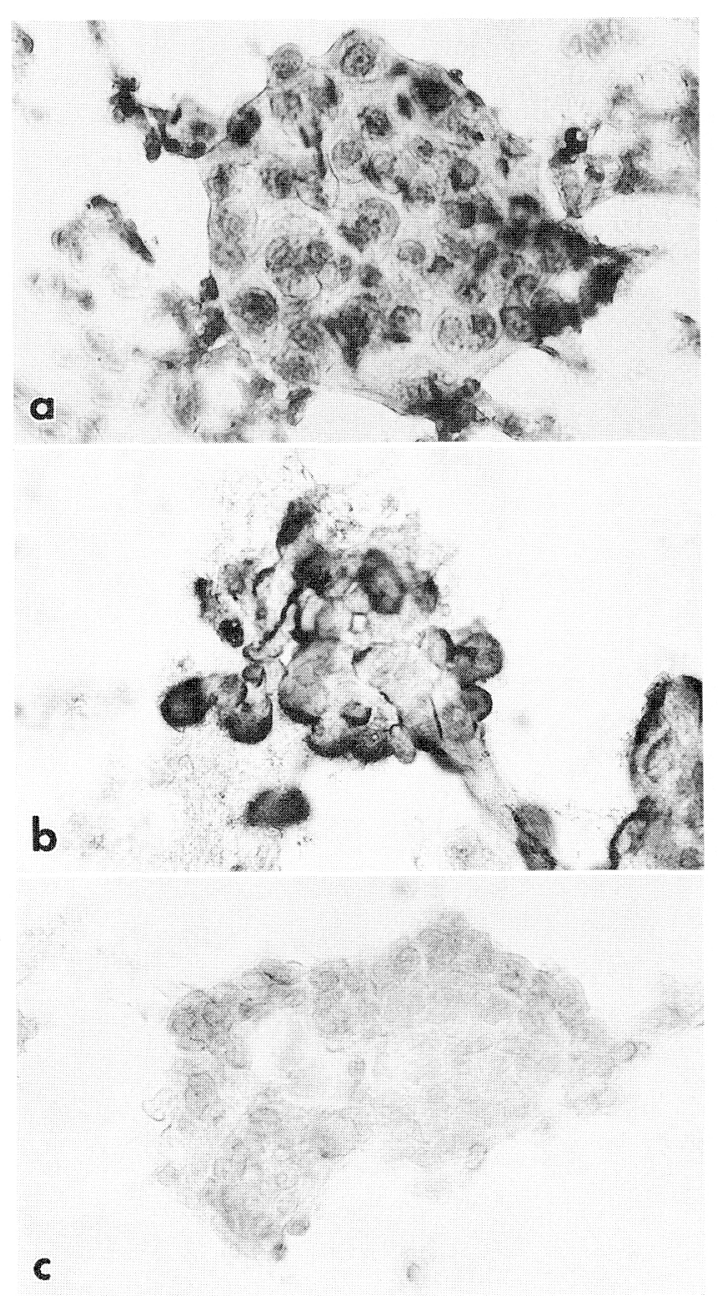

Photo. 2 (a) Pap. stain $\times 40$ : Clustered papillary carcinoma cells $(\times 40)$. (b) DU-PAN- $2 \times 40$ : Positive immunoreaction is observed diffusely in the cytoplasm of papillary carcinoma cells with the cellular surface highlighted $(\times 40)$. (c) CA19-9 ×40: No positive immunoreaction is observed with papillary carcinoma cells $(\times 40)$.

われわれの施設では現在のところ, 術前の組織型確 認に穿刺細胞診を日常的に行っている。滤胞性病変で はリンパ節廓清を行わないか，施行されてもリンパ節 の腫脹が日立つ領域に限って狭い範囲で行われてい る。それに対し，乳頭癌においては比較的広範囲での リンパ節廓清を積極的に適応している。よって, 術前 の組織型推定に細胞診に求められる臨床的意義は高 い。また，体腔液など, 組織学的検索が容易でない検 体では，原発巣が甲状腺由来か否かの識別には，一般 


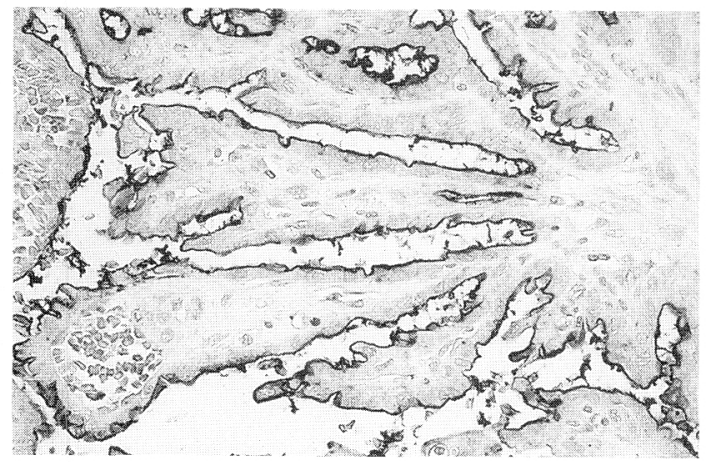

Photo. 3 Papillary carcinoma cells are immunohistochemically positive for DU-PAN-2 along the apical surface (HE stain $\times 10$ ).

にサイログロブリンが第一選択として用いられる。し かし, 経験的に原発巣以外で出現してくる甲状腺乳頭 癌の細胞像は, 特徵的な所見を欠く場合が少なくない ため,このような場合にDU-PAN-2の発現態度を， CA19-9 のそれと比較検討することで, 甲状腺乳頭癌 とその他の腫瘍との鑑別に補助的に用いることが可能 と思われる。

われわれの検索する限り，乳頭癌との鑑別に着目し た免疫細胞化学的検討は少ないが, 興味深いものとし て，丹原らがLeu-M1 (CD15) の有用性を報告してい る ${ }^{23)}$. 免疫細胞化学的に, EMA, Leu-7, Leu-M1 など を用いて乳頭状増殖を示す甲状腺疾患（濾胞癌や濾胞 腺腫などのいわゆる滤胞性病変は含まれていない)の 検討を行った結果, Leu-M1 が乳頭癌に対する感度お よび，特異度ともに高かったと述べている。また，同 時に免疫組織化学的にも検討をして扔り，ごく最近で は今村ら 24)も \&eu-M1 は乳頭癌のマーカーとして有 用であると報告している。

今回の検討結果から注目すべき点は，乳頭癌におけ 万感度や特異度に刘してDU-PAN-2 が相対的にCA19$9 よ り も$ 高いことのみならず，それらの発現性に興味 深い差異・傾向が観察されたことである。すなわち, DU-PAN-2 が院性の場合においてはCA19-9 陽性細胞 が少数であるのに対して，CA19-9が陰性の場合に DU-PAN-2 陽性細胞を比較的多く認める傾向がみられ たことである (Photo. 1，2）。このような症例は前者 が 4 例，後者 6 例であった。

I 型糖鎖抗原の生合成には a 2, 3 sialyltransferase および $a-1 ， 4$ fucosyltransferase の糖転移酵素が関与 しており (Fig. 1)，DU-PAN-2 発現の相対的優位性は a 2, 3 sialyltransferase $の$ 活 性 が $\alpha-1,4$ fucosyltransferase のそれよりも増強していることによる可 能性がある。すなわち, 甲状腺乳頭癌のみならずその 他の正常組織や腫瘍性病変でも観察される DU-PAN-2 抢よびCA19-9 発現のパターンは，これら糖転移酵素 の拮抗あるいは imbalance に依存していることが推察 される、したがって，今後，糖鎖抗原の発現のみなら ず糖転移酵素の活性にも腫瘍化とその形質発現の観点 から検討を加えていきたい。

以上, DU-PAN-2 は甲状腺疾患において乳頭癌に特 異性が高く，濾胞性疾患および他の病変との鑑別に有 効なマーカーとなりうることが期待される。

本論文の要旨は第 43 回日本臨床細胞学会（2002 年 5 月大阪） にて発表した

稿を終えるにあたり，本論文の Photo 作製にご協力いただき ました東海大学医学部共同利用研究施設, 伊東丈夫氏に深謝い たします。

\section{Abstract}

Objective: We compared the immunocytochemical usefulness of DU-PAN-2 and CA19-9 in the differential diagnosis of papillary carcinoma of the thyroid gland.

Study Design: The immunocytochemical expression of DUPAN-2 and CA19-9 was studied in 58 cases of thyroid disease in cluding 30 of papillary carcinoma, 3 of follicular carcinoma, 12 of follicular adenoma, 1 of oxyphilic adenoma, 8 of adenomatous goiter, 1 of Hashimoto thyroiditis, and 2 of Basedow's disease.

Results: The positive ratio of DU-PAN-2 and CA19-9 was as follows : papillary carcinoma $(80 \%, 70 \%)$; follicular adenoma $(0 \%, 8 \%)$; and adenomatous goiter $(0 \%, 25 \%)$. The specificity of DU-PAN-2 for papillary carcinoma was $100 \%$ and CA19-9 $89 \%$. In the cases showing a positive $(+)$ or less reaction for CA19-9, DU-PAN-2 tended to be more strongly expressed.

Conclusions : Compared to CA19-9, DU-PAN-2 was immunocytochemically proven to be more helpful in the differential diagnosis of thyroid papillary carcinoma.

\section{文献}

1) Metzgar, R.S., Gaillard, M.T., Levine, S.J., Tuck, F.L., Bossen, E.H., Borowitz, M.J. Antigens of human pancreatic adenocarcinoma cells difined by murine monoclonal antibodies. Cancer Res $1982 ; 42: 601 \sim 608$.

2) Koprowski, H., Steplewski, Z., Mitchell, K., Herlyn, M., 
Herlyn, D., Fuhrer, P. Colorectal carcinoma antigens detected by hybridoma antibodies. Somatic Cell Genet $1979 ; 5: 957 \sim 972$.

3) Kawa, S., Tokoo, M., Oguchi, H., Furuta, S., Hommma, T., Hasegawa, Y., et al. Epitope analysis of Span-1 and DUPAN-2 using synthesized glycoconjugates sialyllact$\mathrm{N}$-fucopen-taose II and sialyllact-N-tetraose. Pancreas $1994 ; 9: 692 \sim 696$.

4) Sawabu, N., Toya, D., Takemori, Y., Hattori, N., Fukui, M. Measurement of a pancreatic cancer-associated antigen (DUPAN-2) detected by a monoclonal antibody in sera of patients with digestive cancers. Int J Cancer $1986 ; 37: 693 \sim 696$.

5) Haglund, C., Roberts, P.J., Kuuesla, P., Scheinin, T.M., Takela, O., Jalanko, H. Evaluation of CA19-9 as a serum tumour marker in pancreatic cancer. $\mathrm{Br} J$ Cancer $1986 ; 53: 197 \sim 202$.

6) Suzuki, Y., Ichihara, T., Nakano, A., Sakamoto, J., Takagi, H., Nagra, H. High serum levels of DUPAN2 antigen and CA19-9 in pancreatic cancer.Correlation.with immunocytochemical localization of antigens in cancer cells. Hepatogastroenterol $1988 ; 35: 128 \sim 135$.

7) Borowitz, M.J., Tuck, F.L., Sindelar, W.F., Fernsten, P.D., Metzgar, R.S. Monoclonal antibodies against human pancreatic adenocarcinoma : Distribution of DU-PAN-2 antigen on glandular epithelia and adenocarcinomas. J Natl Cancer Inst 1984； $72: 999 \sim 1005$.

8）鴨志田伸吾, 白井正広, 粕谷伯子, 米山桂八, 小野田 登, 堤寛. 癌および非癌組織における (DF3 抗原) およびCA19-9 の免疫組織化学的局在比較. 病理と臨床 $1993 ; 11: 1073 \sim 1079$.

9) Kamoshida, S., Yasuda, M., Serizawa, A., Muramatsu. T., Shinozuka, T., Makino T., et al. Immunohistochemical analy-sis of DU-PAN-2, CA19-9 and Lea in normal uterine glands. AIMM $1999 ; 7: 116 \sim 121$.

10) Muramatsu, T., Yasuda, M., Itoh, J., Kamoshida, S., Hirasawa, T., Murakami, M., et al. Immunohistochemical characterization of DU-PAN-2 expression in endometrial adenocarcinomas, associated with CA19-9 expression. AIMM $1999 ; 7:$ 173 180 .

11）大金直樹, 鴨志田伸吾, 安田政実. 甲状腺乳頭癌の組織 学的鑑別診断におけるDU-PAN-2免疫染色の有用性. 医 学検査 $2000 ; 49: 111 \sim 115$.

12) Kamoshida, S., Ogane, N., Yasuda, M., Muramatsu, T., Bessho, T., Kajiwara, H., et al. Immunohistochemical study of type-1 blood antigen expressions in thyroid tumors : the significance for papillary carcinomas. Mod Pathol $2000 ; 13: 736 \sim 741$.
13) Kamoshida, S., Satoh, Y., Yasuda, M., Kajiwara, H., Tsukinoki, K., Osamura, R.Y. Immunohistochemical heterogeneity of type 1 blood group antigen expressions in testicular germ cell tumors. Oncology Reports. 2002 ; $9: 845 \sim 851$.

14) Vierbuchen, M., Schroder, S., Uhlenbruck, G., Ortmann, M., Fischer, R. CA 50 and CA19-9 antigen expression in normal, hyperplastic, and neoplastic thyroid tissue. Lab Invest $1989 ; 60: 726 \sim 732$.

15）伊達文子, 木村伯子, 名倉 宏. 形質発現からみた甲状 腺乳頭癌の特徵. 病理と臨床 $1996 ; 14: 622 \sim 626$.

16) Muramatsu, T., Yasuda, M., Osamura, R.Y., Kamoshida, S., Yamauchi, I., Kajiwara, H., et al. Clinicopathological analysis of DU-PAN-2 as a tumor maker for endometrial adenocarcinoma in comparison with CA19-9. Acta Histochem Cytochem $2002 ; 35$ (3) : 193 199.

17) Yasuda, M., Murakami, M., Muramatu, T., Itoh, J., Saito, K., kamoshida, S., et al. Immunohistochemical expression of type-1 carbohydrate antigen : availability of DUPAN-2 on pathological and clinical aspects. Acta Histochem Cytochem $2003 ; 36$ (3) : 185 192.

18) Schelfhout, L.J.D.M., Van Muijen, G.N.P., Fleuren, G.J. Expression of keratin 19 distinguishes papillary thyroid carcinoma from follicular carcinoma and follicular thyroid adenoma. Am J Clin Pathol $1989 ; 92: 654 \sim$ 658.

19）細谷哲男, 桜井健司. 甲状腺乳頭癌関連抗原に対する JT-95 の組織反応性. 癌の臨床 $1991 ; 37: 721 \sim 724$,

20) Raphael, S.J., McKeown-Eyssen, Asa, S.L. Highmolecular-weight cytokeratin and cytokeratin-19 in the diagnosis of thyroid tumors. Mod Pathol $1994 ; 7: 295 \sim$ 300.

21) Raphael, S.J., Apel, R.L., Asa, S.L. Detection of highmolecular-weight cytokeratins in neoplastic and nonneoplastic thyroid tumors using microwave antigen retrieval. Mod Pathol $1995 ; 8: 870 \sim 872$.

22) Nozawa, Y., Ami, H., Suzuki, S., Tuchiya, A., Abe, R., Abe, M. Distribution of sialic acid-dependent carbohydrate epitope in thyroid tumors : Immunoreactivity of FB21 in paraffin-embedded tissue sections. Pathol Int $1999 ; 49: 403 \sim 407$.

23）丹原美佳, 大杉典子, 広川満良. 乳頭状増殖を示す甲状 腺疾患一それらの鑑別における Lue-M1 の有用性一. 日 臨細胞誌 $1994 ； 33 ： 631 \sim 634$.

24） 今村好章, 前川秀樹, 森 正樹, 山口直則, 加藤久隆, 福田 優. 甲状腺乳頭癌と滤胞性病変の免疫組織化学的 鑑別. 診断病理 $2003 ; 20: 1 \sim 7$. 